
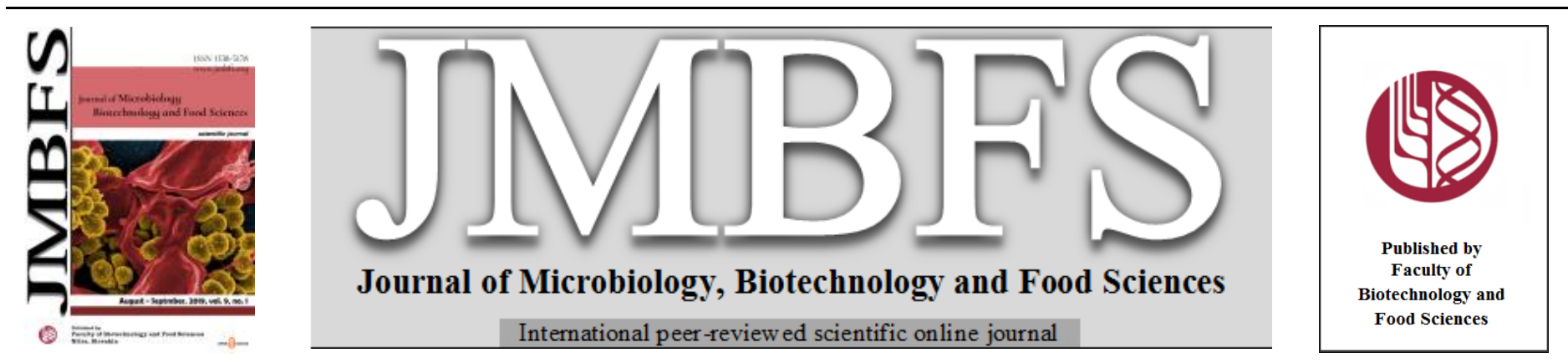

\title{
EVALUATION OF SOME DEFENSIN GENES AGAINST TOMV IN DIFFERENT TOMATO CULTIVARS USING PATHOGENESIS RELATED PROTEIN GENES
}

\author{
Dalia G. Aseel ${ }^{1}$, Reham A. Madian ${ }^{2}$, Sarah A. Aggag ${ }^{* 2}$, Mohamed A. Elseehy ${ }^{2}$ \\ Address(es): Ph.D. Sarah Aggag, \\ ${ }^{1}$ Plant Protection and Biomolecular Diagnosis Department, Arid Lands Cultivation Research Institute, City of Scientific Research and Technological Applications, New \\ Borg El-Arab City, 21934, Egypt. \\ ${ }^{2}$ Department of Genetics, Faculty of Agriculture (El-Shatby), P.O.Box 21545, Alexandria University, Alexandria, Egypt.
}

*Corresponding author: $\underline{\text { sarah.aggag @alexu.edu.eg }}$

doi: 10.15414/jmbfs.2019.9.1.29-33

ARTICLE INFO

Received 21. 1. 2019

Revised 25. 2. 2019

Accepted 25. 2. 2019

Published 1. 8. 2019

Regular article

open $\partial_{\text {ACCESS }}$

\begin{abstract}
The tomato (Solanum lycopersicum) is considered as one of the most important commercially grown vegetables which cultivated through the whole year. From several issues that may face the tomato breeders worldwide are susceptible to many viruses which cause yield losses and reduction in product quality. The goal of this work is to detect and determine some of the defense genes against viral infection diseases in different tomato cultivars infected with tomato mosaic virus (ToMV) by using two molecular techniques: differential display polymerase chain reaction (DD-PCR) and quantitative real time polymerase chain reaction (qRT-PCR) using pathogen related proteins (PRs) to identify and measure expression of pathogen related genes of ToMV. The obtained results have shown differentially expressed banding patterns due to viral infection and variable gene intensities were observed. There were 4 different bands selected randomly, purified and sequenced, the sequence analysis those bands revealed three up-regulated genes (putative permease gene; pathogenesis-related genes transcriptional activator PTI6 gene and linoleate 13S-lipoxygenase 3-1, chloroplast gene), and one down-regulated gene is endochitinase gene. We concluded that the role of the pathogenesis related genes either induced or suppressed during interaction between tomato plant and ToMV but also, the endogluconase $\left(\mathrm{PR}_{1}\right)$ and chitin binding protein (PR4) expression increased during pathogen infection by ToMV, while the expression of chitinase (PR3) decreased/inhibited during infection by ToMV.
\end{abstract}

Keywords: DD-PCR, Pathogenesis related proteins, Real-Time PCR, Sequencing, ToMV

\section{INTRODUCTION}

The tomato as a major worldwide crop belongs to a large family called Solanaceae (Posada, 2016) ranked as the first economical vegetable in the world, accounts for 14\% of world vegetable production (FAO, 2013). In 2016, world production of tomatoes was 177 million tones, with China accounting for $32 \%$ of the total, followed by the European Union, India, the United States, and Turkey as the major producers. Egypt was ranked the sixth internationally in tomato production (FAO, 2016) with $30 \%$ of the total annual cultivated vegetable area, according to the statistics of Egyptian Ministry of Agriculture (2010).

The tomato is susceptible to many viruses which lead to reduce plant growth, decrease the yield and the quality (Najeeb Ullah et al., 2017). Tomato Mosaic virus (ToMV) is widespread all over the world wherever tomato is grown, generally show mosaic and distortion of younger leaves, with internal browning of the fruit wall and fruits may be severely reduced (Nicolay, 2014). The virus is mechanically transmitted by horticultural workers on contaminated hands, clothing, through seed, from leaf and root debris (Green and Kim, 1991). ToMV is Positive single stranded RNA virus belongs to genus Tobamovirus in Family Virgaviridae (King, 2012). Its genome contains four different proteins; $18 \mathrm{KDa}$ encodes the coat protein (CP) essential for genetic material enclosed in a protein coat systemic spread of the virus (Ishibashi and Ishikawa, 2016), $130 \mathrm{KDa}$ and $180 \mathrm{KDa}$ proteins both involved in RNA replication, $30 \mathrm{KDa}$ encodes for movement protein according to Arinaitwe et al. (2018).

Pathogenesis related proteins (PRs) are group of plant-coded proteins classified and categorized into seventeen families from PR-1 to PR-17 (Ritu Singh et al., 2014), induced in response to different stresses such as: wounding, exposures to salinity, drought, cold, heavy metals, air pollutants and ultraviolet rays and pathogen attacks such as fungi, bacteria and viruses determined by Agrios (1997). Furthermore, PR proteins induces a hypersensitive response characterized by localized and rapid death of cells (necrosis) surrounding the site of pathogen infection which inhibit multiplication and further spreading of infection (Heath, 2000).
The objectives of this study were to detect and identify some defensin genes against viral infection using pathogen related proteins PRs in different tomato cultivars infected with ToMV.

\section{MATERIALS AND METHODS}

The present study was carried out in the Plant Protection and Biomolecular Diagnosis Department, Arid Lands Cultivation Research Institute, City of Scientific Research and Technological Applications, Borg El-Arab, Alexandria (2017).

\section{Plant collection's areas}

Both tomato leaves (healthy and infected) were collected from six different areas in Alexandria and El-Behira (El-Nubariya, Abo Hommas, El-Amria, Apis, Alexandria El-Kilo 43, and El-Behira-El-Dalangat) (Table 1) (Figure 1).

Table 1 Areas and the classes of the collected tomato sample

\begin{tabular}{cccc}
\hline Code number & Area & Class & Type \\
\hline 1 & El-Amria & Catalina 522 & Control \\
$1^{\prime}$ & El-Amria & Catalina 522 & Infected \\
\hline 2 & Alexandria El-Kilo 43 & Giza 186 & Control \\
$2^{\prime}$ & Alexandria El-Kilo 43 & Giza 186 & Infected \\
\hline 3 & El-Behira-El-Dalangat & El-basha 77 & Control \\
$3^{\prime}$ & El-Behira-El-Dalangat & El-basha 77 & Infected \\
\hline 4 & Abo-Hommas & Maleaka & Control \\
$4^{\prime}$ & Abo-Hommas & Maleaka & Infected \\
\hline 5 & Abo-Hommas & Peto 86 & Control \\
$5^{\prime}$ & Abo-Hommas & Peto 86 & Infected \\
\hline 6 & Apis & Maleaka & Control \\
$6^{\prime}$ & Apis & Maleaka & Infected \\
\hline 7 & El-Nubariya & Maleaka & Control \\
$7^{\prime}$ & El-Nubariya & Maleaka & Infected \\
\hline
\end{tabular}



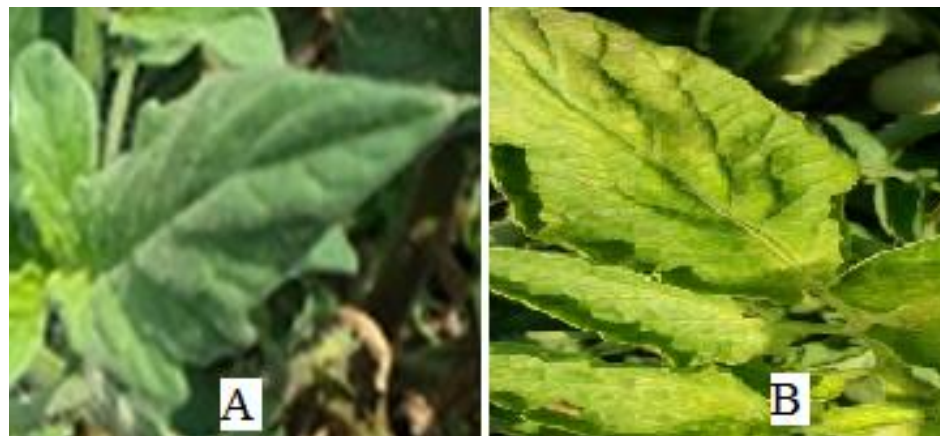

Figure 1 Naturally symptoms of tomato mosaic virus (ToMV); A. Healthy tomato leaves, B. Infected tomato leaves with ToMV.

\section{Extraction of total RNA, cDNA synthesis and detection of ToMV-CP gene} using PCR

The RNA extraction was performed for cultivars by Saroj et al. (2014) using Trizol reagent (easy-BLUETM, INTRON Biotechnology, Korea) as described by the manufacturer's protocol. Complementary DNA (cDNA) was synthesized by reverse transcribing total RNA in $20 \mu \mathrm{L}$ reaction contained: $3 \mu \mathrm{L}$ of total RNA was added to reaction mixture containing of $5 \mu \mathrm{L}$ of oligo-dT primer (10 Pmol $/ \mu \mathrm{L}), 2.5 \mu \mathrm{L}$ of dNTP $(10 \mathrm{~mL}), 2.5 \mu \mathrm{L}$ of buffer $(10 \mathrm{x}), 0.3 \mu \mathrm{L}$ of reverse transcriptase (M-MULV reverse transcriptase 200 unit $/ \mu \mathrm{L}$, Biolabs, England), and $6.7 \mu \mathrm{L}$ sterile water to final volume of $20 \mu \mathrm{L}$ (Hafez et al., 2013). The reaction was mixed gently by pipetting and placed in thermos-cycler (MJ Research, Inc., PTC-100 ${ }^{\mathrm{TM}}$ Programmable thermal controller, USA). The amplification was programmed as following: $37^{\circ} \mathrm{C}$ for $2 \mathrm{hrs}$, followed by inactivation at $65^{\circ} \mathrm{C}$ for $20 \mathrm{~min}$, and cooling at $4^{\circ} \mathrm{C}$. Specific primers for ToMV-CP (Forward 5`CGGAAGGCCTAAACCAAAAAG-3` and Reverse 5``
ATTTAAGTGGAGGGA AAAACACT-3`) were used to identify and amplify the CP gene (Letschert et al., 2002). The PCR reaction was carried out in a 25 $\mu \mathrm{L}$ volume contained the following components: $12.5 \mu \mathrm{L}$ PCR master mix (Applied Biotech, Egypt), $8.5 \mu \mathrm{L}$ distilled water, $1 \mu \mathrm{L}$ of ToMV-CP forward primer, $1 \mu \mathrm{L}$ ToMV-CP reverse primer, and $2 \mu \mathrm{L}$ cDNA as a template Amplification was performed in (Agilent technologies sure cycler-8800, USA) and by the following cycling parameters: $3 \mathrm{~min}$ initial denaturation step at $95^{\circ} \mathrm{C}$, 1 min denaturation step at $94^{\circ} \mathrm{C}, 1 \mathrm{~min}$ annealing step at $60^{\circ} \mathrm{C}$ and $1 \mathrm{~min}$ elongation step at $72^{\circ} \mathrm{C}$ for 35 cycles with a final 5 min elongation step at $72^{\circ} \mathrm{C}$ and cooling to $4^{\circ} \mathrm{C}$ (Hafez et al., 2013). A $7 \mu \mathrm{L}$ of PCR amplified products were separated by agarose gel electrophoresis $(2 \%)$ in $0.5 \mathrm{x}$ TBE buffer at $150 \mathrm{~V}$ for 1 $\mathrm{hr}$. The gel was stained with ethidium bromide at a concentration of $0.5 \mathrm{mg} / \mathrm{ml}$. One hundred bp Plus Blue DNA ladder (Gene ON) was used as a molecular weight standard. Bands were visualized on a UV trans-illuminator and photographed using gel documentation system (IN GENUS SYNGENE BIO Imaging, USA)

Detection of viral proteins in ToMV using Sodium Dodecyl Sulphate Polyacrylamide Gel Electrophoresis (SDS-PAGE)

Protein electrophoresis provides a precise method for assaying variation between cultivars (El-Sabrout and Aggag, 2015). Proteins are denatured by adding a detergent of SDS to separate samples exclusively according to their molecular weight. SDS-PAGE was carried out using discontinuous buffer system mentioned by Hames and Rickwood (1990).

Differential Display-Polymerase Chain Reaction (DD-PCR) of pathogenesis related proteins against ToMV

Seven primers of PRs were used in this study shown in Table (2). DD-PCR amplifications were carried out by conditions showed in Rashad et al. (2018).

Table 2 The sequence of oligonucleotide primers used in this study

\begin{tabular}{lcc}
\hline Primer & Designation & \multicolumn{1}{c}{ Sequence (5'-3') } \\
\hline Endogluconase $\left(\mathrm{PR}_{1}\right)$ & Forward & TTC TTC CCT CGA AAG CTC AA \\
Endogluconase $\left(\mathrm{PR}_{1}\right)$ & Reverse & CGC TAC CCC AGG CTA AGT TT \\
\hline Chitinase $\left(\mathrm{PR}_{3}\right)$ & Forward & CGG TGG TAC TCC TCC TGG ACC C \\
Chitinase $\left(\mathrm{PR}_{3}\right)$ & Reverse & CGG CGC CAC GGT CGG CGT CTG A \\
\hline Chitin Binding Protein $\left(\mathrm{PR}_{4}\right)$ & Forward & GAC CTG AAT GCG GTC GTC AAG G \\
Chitin Binding Protein $\left(\mathrm{PR}_{4}\right)$ & Reverse & AGC ATG TTT CTG GAA TCA GGC TG \\
\hline Thaumatin-like Protein $\left(\mathrm{PR}_{5}\right)$ & Forward & ATG GGC TAC TTG ACA TCT TCT T \\
Thaumatin-like Protein $\left(\mathrm{PR}_{5}\right)$ & Reverse & TTA TGG GCA AAA AAC AAC CCT \\
\hline Phenylalanine ammonia lyase $(\mathrm{PALPR} 11)$ & Reverse & CGA GCA ATA AGA AGC CAT CGC AAT \\
\hline$\beta$-Actin (reference gene) & Sense & GTG GGC CGC TCT AGG CAC CAA \\
$\beta$-Actin (reference gene) & Antisense & CTC TTTG ATG TCA CGC ACG ATT TC \\
\hline
\end{tabular}

Sequencing and phylogenetic relationship of up and down regulated genes of ToMV

The result of DD-PCR product was excised from the gel and purified using a BIO BASIC INC.EZ-10 spin column PCR products purification kit. The purified genes were sequenced from some selected, up and down regulated, bands using the automated sequencer of Sanger method by Macrogene Company (Korea) DNA homology searches were carried out with the National Center for Biotechnology Information (NCBI) databases, using the basic local alignmen search tool (BLAST) network service (Altschul et al., 1990). The sequences were used for comparison using MEGA4 (Tamura et al., 2007) and phylogeny was tested with bootstrap method. The phylogenetic tree was analyzed and generated based on UPGMA static analysis (Tamura et al., 2007).

Quantitative Real Time PCR of some Pathogenesis related proteins (PRs) against ToMV

Real-time PCR was carried out using SYBR Green PCR Master Mix (Applied Biotech, Egypt). Three primers were used in this study; endogluconase (PR1), Chitinase (PR3), chitin binding protein (PR4) Table (2), to determine the expression of defensin genes in tomato. The components were combined in a PCR-reaction tube and adjusted to a final volume of $25 \mu \mathrm{l}$ with distilled sterile water according to (Rashad et al., 2018)

\section{Data Analysis}

The data set of both, healthy and infected, samples was analyzed with appropriate program for estimation of the relative expression of genes using Real Time PCR. The results normalized to housekeeping gene primers $\beta$-Actin gene (Reference gene) (Table 2) using (Rotor-Gene Q Qiagen, German). The equations show the mathematical model of the relative expression ration for the real time PCR (Schmittgen and Livak, 2008).

\section{RESULTS}

\section{Symptoms of plant collection}

The healthy and naturally ToMV infected tomato samples were collected randomly from different regions in Alexandria and El-Behira (Table 1). The ToMV infected plants exhibiting symptoms of light or dark green mottling or mosaic, with distortion of younger leaves, systemic chlorosis, local necrotic lesions, upward leaf rolling and a severe attenuation leaves or a "fernlike" appearance (Figure1)

\section{Reverse Transcriptase (RT-PCR)}

The ToMV infected samples were amplified by RT-PCR using CP gene specific primers. The resulted PCR amplicon of $700 \mathrm{bp}$ in size of the coat protein gene of ToMV was detected in all seven collected tomato cultivars (Figure 2).

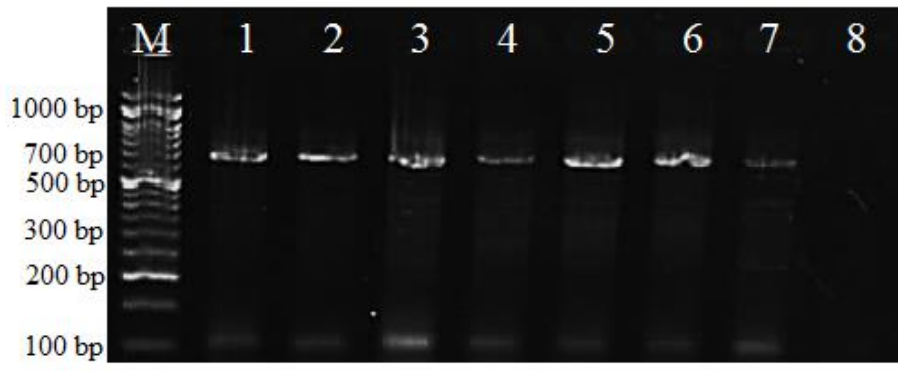

Figure 2 PCR product of Tomato mosaic virus- coat protein (ToMV-CP) gene using $2 \%$ agarose gel electrophoresis. M= DNA ladder; Lane 1= Catalina 522 Lane 2= Giza 186; Lane 3= El-basha 77; Lane 4= Maleaka/Abo - hommas; Lane 5= Peto 86; Lane 6= Maleaka/ Apis; Lane 7= Maleaka/El-Nubariya; Lane 8= Negative control (Healthy tomato plant). 


\section{SDS-PAGE}

SDS Protein Electrophoresis was carried to detect and determine the protein expression level in the ToMV infected tomato plant. SDS-PAGE profiles of different tomato cultivar infected by ToMV were compared with healthy tomato samples, and by which, we detected 4 different types banding pattern (18 KDa, $30 \mathrm{KDa}, 130 \mathrm{KDa}, 180 \mathrm{KDa}$ ) that are corresponds to the antiviral proteins. The $18 \mathrm{KDa}$ protein band represents coat protein gene of ToMV that was detected in ToMV-Peto86 and Maleaka cultivars, $30 \mathrm{KDa}$ band is movement protein of ToMV, $130 \mathrm{KDa}$ protein band represents replication gene of ToMV that was detected in Cataliana522 cultivar. Additionally, $180 \mathrm{KDa}$ second replication protein of ToMV was detected in Cataliana522, Giza186 and Maleaka cultivars (Figure 3).

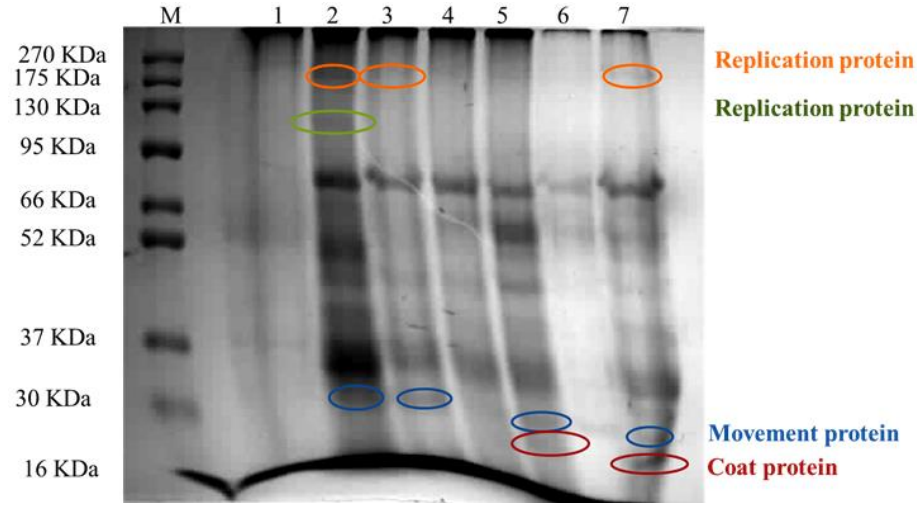

Figure 3 SDS-PAGE analysis of Tomato mosaic virus (ToMV) infected tomato leaves. Lane M: protein marker; Lane 1, healthy sample (Control); then infected samples: Lane 2, Cataliana522; Lane 3, Giza186; Lane 4, (El-basha77); Lane 5, (Maleaka); Lane 6, (Peto86); Lane 7, Maleaka.

\section{Differential Display Polymerase Chain Reaction (DD-PCR)}

The DD-PCR result for endogluconase gene forward primer (PR1) indicated that there were about 23 up -regulated genes with different lengths ranged from 190 to $800 \mathrm{bp}$ in Catalina 522, Giza 186, El-Basha 77, Peto 86 and Maleaka, which are infected by TMV. Comparing infected with healthy samples of same cultivars, there were about 26 down-regulated genes with different molecular weight ranged from 220 to $700 \mathrm{bp}$. Similarly for endogluconase gene reverse primer (PR1) revealed that, 15 bands of up-regulated genes ranged from 110 to 500 bp in Giza186, El-basha77, Peto 86 and Maleaka infected by ToMV. On the contrary, 22 bands were observed with molecular weight ranged from 110 to 400 $\mathrm{bp}$ for all healthy samples. Moreover, only one band at $400 \mathrm{bp}$ was showed changing in the intensity from low (control Peto86) to high intensity (infected sample Peto86). The result from DD-PCR using chitinase arbitrary primer (PR3), it was observed that, two up-regulated genes with length of 350 and $450 \mathrm{bp}$ for Peto86-infected by ToMV. In contrast, only one band down-regulated gene with length $350 \mathrm{bp}$ for Giza186-control sample. For PR4, 9 bands of up-regulated genes ranged from 200 to 380 bp in Giza186, Maleaka and Peto86 were infected by ToMV. On the contrary, for control samples-Giza186, El-basha77 and Maleaka, 4 bands of down-regulated genes were observed ranged from 220 to $380 \mathrm{bp}$. The banding profiles that obtained from DD-PCR using Thaumatin-like protein reverse primer (PR5) revealed 16 bands ranged from 280 to $580 \mathrm{bp}$ for all infected samples. Also, 13 bands of down-regulated genes were observed ranged from 300 to $500 \mathrm{bp}$ for control samples (Giza186, Peto86 and Maleaka). The DDPCR banding profiles which amplified using PR5 showed that 11 bands of upregulated genes induced ranged from 250 to $500 \mathrm{bp}$ for infected samples (Catalina 522, El-basha77, Peto86 and Maleaka). Moreover, five bands of downregulated genes were observed in control samples (Giza186, Peto86 and Maleaka) ranged from 200 to $380 \mathrm{bp}$. Finally, the phenylalanine ammonia-lyase primer (PAL PR11) gave only one down-regulated gene with molecular weight $300 \mathrm{bp}$ for El-Basha77 control sample (Figure 4).
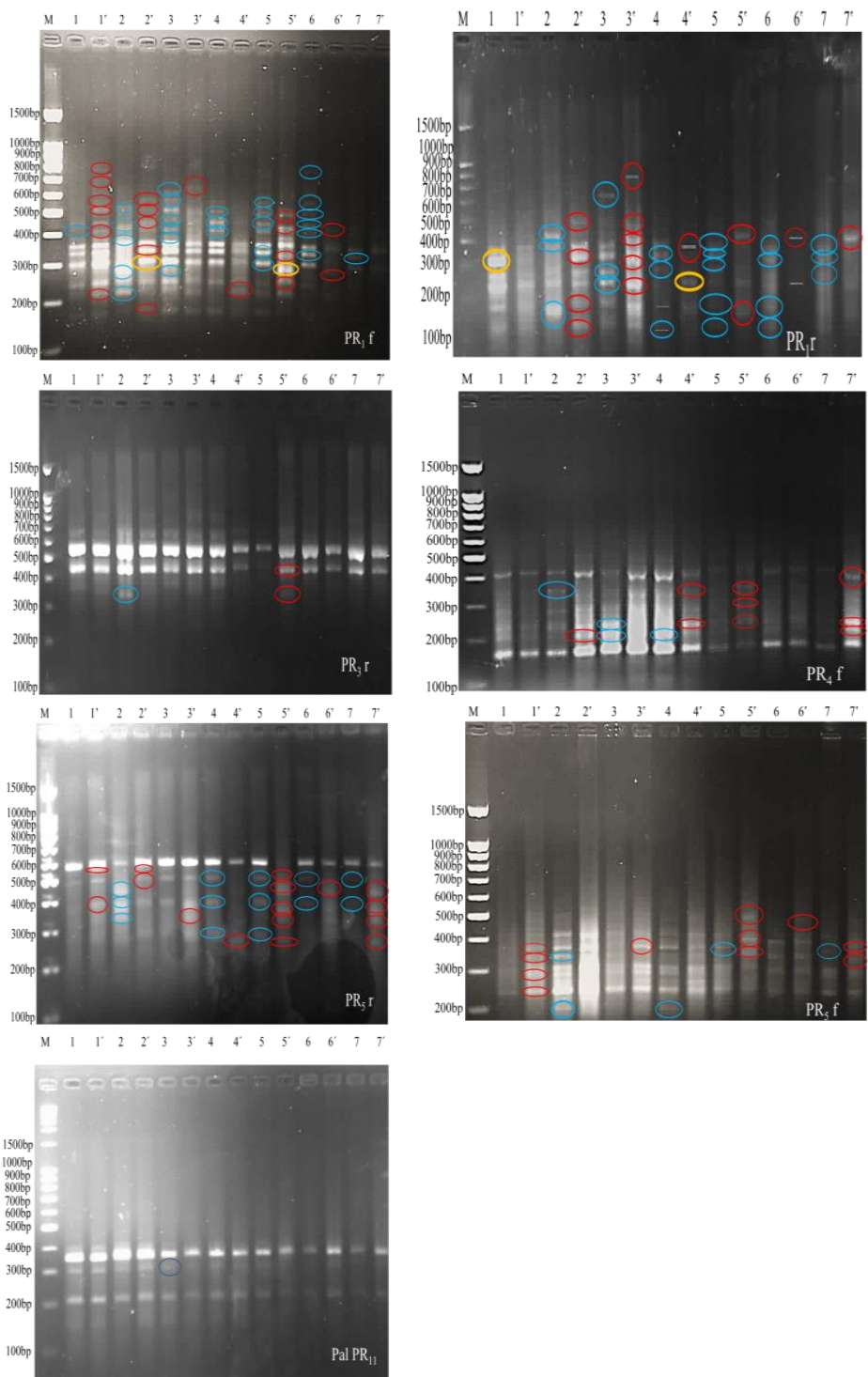

Figure 4 Differential display PCR (DD-PCR) using the Endogluconase $\left(\mathrm{PR}_{1}\right)$, Chitinase $\left(\mathrm{PR}_{3}\right)$, Chitin Binding Protein $\left(\mathrm{PR}_{4}\right)$, Thaumatin-like Protein $\left(\mathrm{PR}_{5}\right)$ and Phenylalanine ammonia-lyase $\left(\mathrm{PAL} \mathrm{PR}_{11}\right)$ primer for scanning up and down regulated genes in different tomato cultivars both healthy and infected by ToMV. (1) control-Catalina 522, (1') infected-Catalina 522,

(2) control-Giza 186, (2') infected-Giza 186,

(3) control-El-basha 77, (3') infected-El-basha 77,

(4) control-Maleaka, (4') infected-Maleaka,

(5) control-Peto 86, (5') infected- Peto 86,

(6) control-Maleaka, (6') infected-Maleaka,

(7) control-Maleaka, (7') infected-Maleaka

* Yellow Circle indicated for the selected randomly sequenced genes.

* Red Circle indicated up-regulated gene.

* Blue Circle indicated down-regulated gene.

Sequencing and phylogenetic tree for up and down regulated genes resulted from DD-PCR

Four bands of up and down regulated genes were randomly selected from each cultivars, purified and sequenced by using forward endogluconase (PR1) and reverse endogluconase (PR1) primers. The nucleotide sequence of those genes was deposited in the GenBank. The sequences analysis showed that the up and down regulated genes characterized in the present study was very closely cluster with putative permease and putative protein phosphatase genes (up-regulated gene), pathogenesisrelated, genes transcriptional activator PTI6 (up-regulated gene), endochitinase (down-regulated), linoleate 13S-lipoxygenase 3-1, chloroplast (up-regulated gene) (Figure 5). 


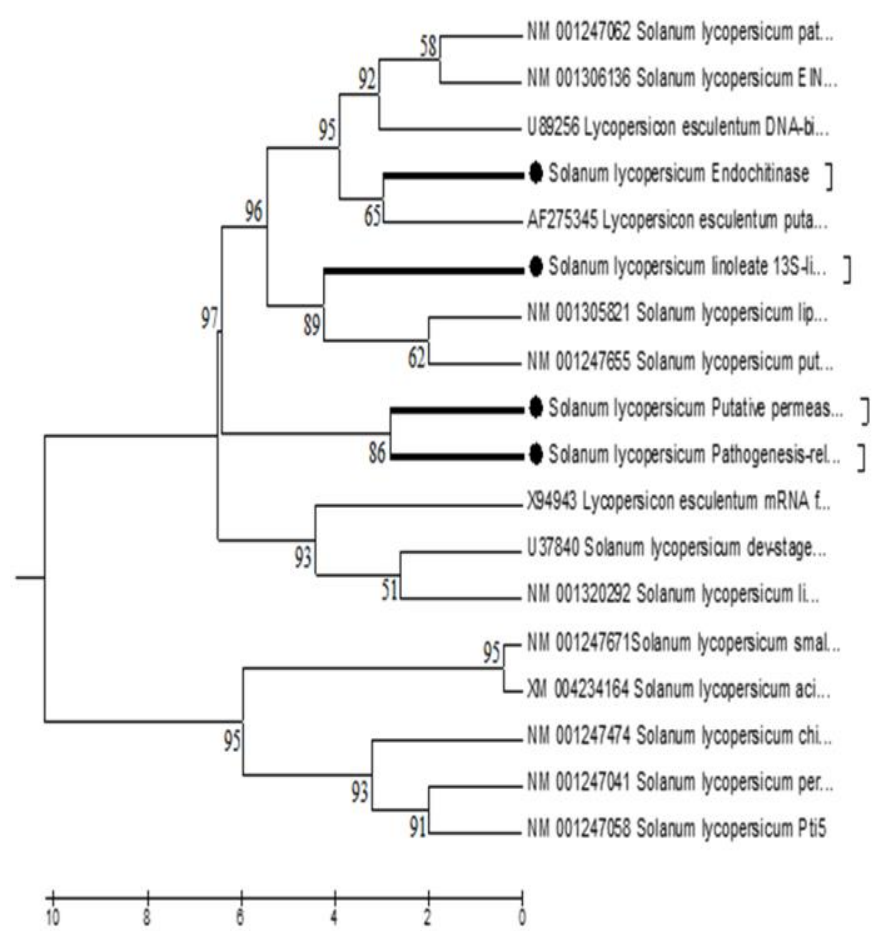

Figure 5 Dendogram illustrate the phylogenetic relationships of DNA nucleotide sequences of the up-down regulated gene and comparing with other genes of tomato available in NCBI.

\section{Quantitative Real Time -PCR amplification of some PRs against ToMV}

RT-PCR was performed in triplicate on the corresponding cDNA synthesized from each sample. RT-PCR was used to detect and determine the expression of three defensin genes of tomato cultivars infected by ToMV (Figure 6). All results were normalized to $\beta$-actin gene as reference gene.
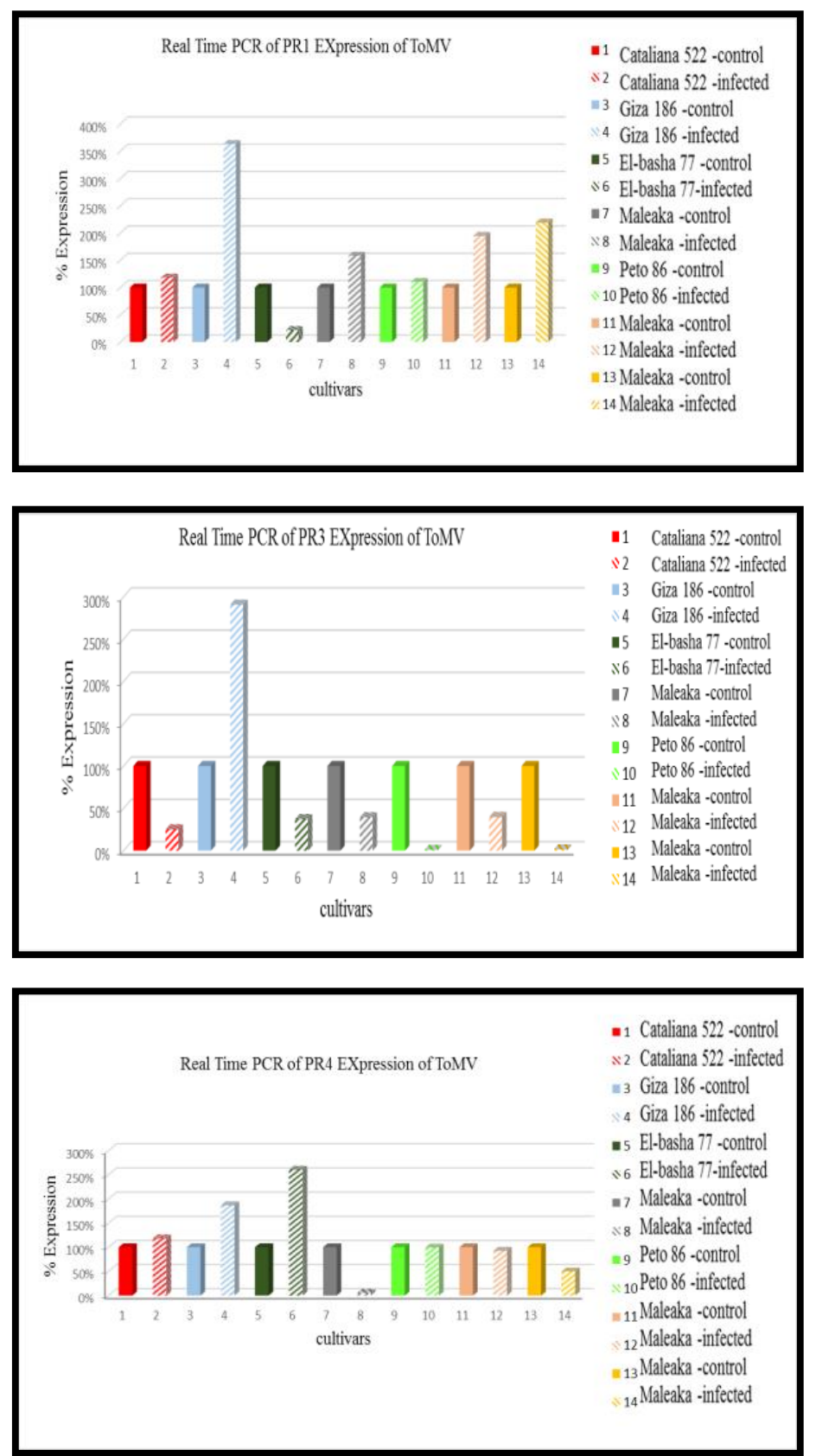

Figure 6 Histogram of Real Time PCR illustrates the endogluconase $\left(\mathrm{PR}_{1}\right)$, the Chitinase $\left(\mathrm{PR}_{3}\right)$ and the Chitin binding protein $\left(\mathrm{PR}_{4}\right)$ gene expression in tomato cultivars infected with ToMV.

\section{DISCUSSION}

The current study aims to detect and identify some defense genes against viral infection using PRs in different tomato cultivars infected with ToMV. To achieve these purposes, molecular techniques were carried out such as: multiplex PCR, RT-PCR, specific PCR, sequencing, phylogenetic tree, DD-PCR and RT-PCR using PRs to measure expression of Pathogen Related genes of ToMV. SDS PAGE was used to determine the ToMV proteins accordingly to data revealed that ToMV genome encodes 4 different proteins which are important for packaging of viral RNA, virus movement and replication. These results are in harmony with the study carried by Meshi et al. (1992).

The multiplex PCR used for detection and differentiation of mixed infection in collected tomato leaves samples. The amplification showed that a fragment with about 700 bp was amplified for tomato samples infected only by ToMV and no bands were observed for any other virus except ToMV.

DD-PCR was used to determine ToMV effect on the plant defense gene expression and to try understanding part of the plant virus interaction. To achieve these purposes we used healthy tomato (control) to compare it with the different tomato cultivar leaves infected by ToMV. Moreover, the obtained result showed differentially expressed banding patterns due to viral infection and variable gene intensities were observed. All these data mean that virus affect the plant defense genes may be up-regulated (turned on) and down-regulated (turned off). 
Putative permease gene (Jointless) initiates the abscission zone formation in flower pedicels demonstrated by Butler (1936). This gene, spontaneous mutation, has important role in reproductive organ formation in tomato plants which has a central role in coordinating gene expression underlying the differentiation of the pedicel abscission zone, this gene encodes into different function such as; transcriptional regulator, transferase activity, transferring glycosyl groups, glycosyl transferase, carbohydrate metabolism and transmembrane transport (Mao et al., 2000; Budiman et al., 2004).

Pathogenesis-related genes transcriptional activator PTI6, SICRF1, this gene was able to bind specifically DNA binding domain, like other ERF proteins at the GCC-box found in the promoter regions of various pathogenesis-related (PR) genes. Furthermore, this gene activates the expression of some PR genes when expressed in Arabidopsis (Gu et al., 2002). SICRF1 may play a role in plan defense or biotic stress response reported by Park et al. (2001). PTI6/SICRF1 linked to other processes such as cytokinin regulation including disease resistance and stress responses (Zhou et al., 1997; Park et al., 2001; Gu et al., 2002). Acts as a transcriptional activator, Binds to the GCC-box, Pathogenesis-related promoter element, activate the defense genes of plants, play a role in plant defense or biotic stress response.

Endochitinase found to be involved in important biological functions such as carbohydrate metabolic process, cell wall macromolecule catabolic process, chitin catabolic process, chitinase activity, chitin binding.

Linoleate 13S-lipoxygenase 3-1, chloroplast (LOXD), plant lipoxygenase involved in a number of diverse aspects of plant physiology including growth and development, pest resistance, metal ion binding, oxido reductase activity and senescence or responses to wounding (Yuan et al., 2013). Results of the present study are in agreement with those obtained by Zhang $\boldsymbol{e t}$ al. (1998); Stotz et al. (2009) and Hafez et al. (2013).

Endochitinase is closely related to Lycopresicon esculentum putative permease gene with nucleotide sequence identity of $65 \%$. Additionally, linoleate 13Slipoxygenase $3-1$, chloroplast) is closely related to lipid desaturase like protein and putative uncoupling protein with similarity of $89 \%$. Also, Putative permease gene has high nucleotide sequence identity $96 \%$ with putative uncoupling protein, EIN3-binding F-box protein 2, lipid desaturase like protein, pathogenesis-related genes transcriptional activator PTI5, pathogenesis related transcriptional activator PTI6, endochitinase and linoleate 13S-lipoxygenase 3-1, chloroplast. Finally, Pathogenesis-related genes transcriptional activator PTI6 is closely related to pathogenesis-related genes transcriptional activator PTI5, endochitinase and linoleate 13S-lipoxygenase 3-1, chloroplast, EIN3-binding Fbox protein 2 , lipid desaturase like protein, putative uncoupling protein with nucleotide sequence identity of $96 \%$.

In order to determine the expression of the three understudy defense genes: endogluconase (PR1); Chitinase (PR3) and Chitin Binding Protein (PR4) which were detected in the different tomato cultivar leaves infected by ToMV comparing with control samples, infected tomato leaves by ToMV elevated the expression of some defense genes. Both endogluconase (PR1) and Chitin Binding Protein (PR4) expression increased during pathogen infection by ToMV, while the expression of Chitinase (PR3) decreased or inhibited during infection by ToMV.

\section{CONCLUSION}

The virus affects the plant defense genes may be up-regulated (turned on) and down-regulated (turned off) during interaction between tomato plant and ToMV These findings which implicate the phenomenon of plant possess an immune system to defend themselves against pathogen interaction. This lead to activation of defense mechanism and regulation of gene expression of various pathogenesis related protein. It implied that from all tomato cultivars used in this study, the best 2 cultivars expressed high defense system against ToMV are Catalina 522 and Giza 186. Therefore, we recommended using those 2 cultivars for obtained healthy tomato plants and reduced crop losses.

\section{REFERENCES}

AGRIOS, G.N. 1997. Plant Pathology. $4^{\text {th }}$ ed. San Diego: Academic Press, 93114

ALTSCHUL STEPHEN, F., GISH, W., MILLER, W., MYERS, E.W., LIPMAN,

D.J. 1990. Basic local alignment search tool. J Mol Biol, 215: 403-410.

http://dx.doi.org/10.1016/S0022-2836(05)80360-2

ARINAITWE, W., OCHWO-SSEMAKULA, M., MBEWE, W.K.,

SSERUWAGI, P., KYAMANYWA, S., ERBAUGH, M., MILLE, S., QU, F.

2018. Molecular Characteristics of Tomato Mosaic Virus Infecting Tomato in Uganda. Afr Crop Sci J, 26(3): 433-445. http://dx.doi.org/10.4314/acsj.v26i3.8 BUTLER, L. 1936. Inherited characters in the tomato. II. Jointless pedicel. $J$ Hered, 37: 25-26. http://dx.doi.org/10.1007/s10681-008-9754-x

BUDIMAN, M.A., CHANG, S-B., LEE, S., YANG, T.J., ZHANG, H-B., DE JONG H., WING, R. A. 2004. Localization of jointless-2 gene in the centromeric region of tomato chromosome 12 based on high resolution genetic and physical mapping. Theor Appl Genet, 108: 190-196. http://dx.doi.org/10.1007/s00122$\underline{003-1429-3}$
Department of Agriculture statistics, Ministry of Agriculture and land Reclamation, Egypt. 2010. Tomato (lycopresicon esculentum), 34-36. EL-SABROUT, K., AGGAG, S.A. 2015. Use of inter simple sequence repeats and protein markers in assessing genetic diversity and relationships among four rabbit genotypes. World Rabbit Sci, 23: 283-288.

http://dx.doi.org/10.4995/wrs.2015.3912

FAO, Food and Agriculture Organization. 2013. http.//www.fao.org.

FAOSTAT of the United Nations, 2016.

GREEN, S.K., KIM, J.S. 1991. Characterization and control of viruses infecting peppers. A Catalog. Tech. Bull. AVRDC. 18, 60

GU, Y.Q., WILDERMUTH, M.C., CHAKRAVARTHY, S., LOH, Y.T., YANG, C., HE, X., HAN, Y., MARTIN, G.B. 2002. Tomato transcription factors pti4, pti5, and pti6 activate defense responses when expressed in Arabidopsis. Plant Cell, 14: 817-831. http://dx.doi.org/10.1105/tpc.000794

HAFEZ, E.E., HASHEM, M., BALBAA, M.M., El-SAADANI, M.A., AHMED, S.A. 2013. Induction of New Defensin Genes in Tomato Plants via Pathogens Bio control Agent Interaction. J Plant Pathol Microb, 4: 167.

http://dx.doi.org/10.4172/2157-7471.1000167

HAMES, B.D., RICKWOOD, D. 1990. Gel Electrophoresis of Proteins, A practical Approach. Second Edition IRL Press at Oxford University Press, Oxford, UK; 383.

HEATH, M.C. 2000. Hypersensitive response-related death. Plant Mol Biol, 44 321-334. https://dx.doi.org/10.1023/A:1026592509060

ISHIBASHI, K., ISHIKAWA, M. 2016. Replication of Tobamovirus RNA. Annu Rev Phytopathol, 54: 55-78. http://dx.doi.org/10.1146/annurev-phyto080615-100217

KING, M., LEFKOWITZ, E. 2012 .Virus taxonomy: Classification and Nomenclature of Viruses: Ninth ICTV Report. London: Academic Press; 1327. LIANG, P., PARDEE, A.B. 1992. Differential display of eukaryotic messenger RNA by means of the polymerase chain reaction. Sci, 257: 967-971.

https://dx.doi.org/10.1126/science.1354393

MAO, L., BEGUM, D., CHUANG, H.W., BUDIMAN, M.A., SZYMKOWIAK, E.J., IRISH, E.E., WING, R.A. 2000. Jointless is a MADS-box gene controlling tomato flower abscission zone development. Nature, 406: 910-913. http://dx.doi.org/10.1038/35022611

NAJEEB ULLAH, ASAD, A., MUSHARAF, A., MUHAMMAD, F.,

NASEERUD DIN, FAYAZ, A. 2017. Evaluation of tomato genotypes against tomato mosaic virus (ToMV) and its effect on yield contributing parameters. Pak J Bot, 49(4): 1585-1592

NIKOLAY, P. 2014. Damaging Effects of Tomato Mosaic Virus and Potato Virus Y on Tomato Plants. Science \& Technologies Plant studies. 4-6.

PARK, K.S., AHN, I.P., KIM, C.H. 2001. Systemic resistance and expression of the pathogenesis-related genes mediated by the plant growth promoting rhizo bacterium Bacillus amyloliquefaciens EXTN-1 against anthracnose disease in cucumber. Mycobiol, 29: 48-53.

http://dx.doi.org/10.1080/12298093.2001.12015759

POSADA, L. 2016. Solanum Lycopersicum. A Monograph. Agri Sci Colegio

Bolivar, 9

RASHAD, Y.M., ASEEL, D.G., HAFEZ, E.E. 2018. Antifungal potential and defense gene induction in maize against Rhizoctonia root rot by seed extract of $\begin{array}{llll}\text { Ammi visnaga } & \text { (L.) Lam. Phytopathol Mediterr, 57:73 }\end{array}$ 88. http://dx.doi.org/10.14601/Phytopathol_Mediterr-21366

RITU, S., JAGESH, T., VINAY, Sh., SINGH, B.P., SHASHI, R. 2014. Role of Pathogen related protein families in defence mechanism with potential role in applied biotechnology. IJAR, 2(8): 210-226.

SCHMITTGEN, T.D., LIVAK, K.J. 2008. Analyzing real-time PCR data by the comparative 15 CT method. Nat Protoc, 3: 1101-1108. http://dx.doi.org/10.1038/nprot.2008.73

SAROJ, K.S., GURWINDER, K.A., AMANDEEP, K. 2014. Rapid and Reliable Method of High-Quality RNA Extraction from Diverse Plants. AJPS, 5: 31293139. http://dx.doi.org/10.4236/ajps.2014.521329

STOTZ, H.U., SPENCE, B., WANG, Y. 2009. A defensin from tomato with dual function in defense and development. Plant Mol Biol, 71: 131-143. http://dx.doi.org/10.1007/s11103-009-9512-Z

TAMURA, K., DUDLEY, J., NEI, M., KUMAR, S. 2007. MEGA4: Molecular Evolutionary Genetics Analysis (MEGA) software version 4.0. Mol Biol Evol, 24: 1596-1599. http://dx.doi.org/10.1093/molbev/msm092

ZHANG, W., HAN, D.Y., DICK, W.A., DAVIS, K.R., HOITINK, H.A.J. 1998

Compost and compost water extract induced systemic acquired resistance in cucumber and Arabidopsis. Phytopathol, 88: 450-455.

http://dx.doi.org/10.1094/PHYTO.1998.88.5.450 ZHOU, X.P., LIU, Y.L., CALVERTL, M.C., OTIM-NAPE, G.W., ROBINSON, D.J., HARRISON, B.D. 1997. Evidence that DNA-A of a gemini-virus associated with severe cassava mosaic disease in Uganda has arisen by interspecific recombination. J Gen Virol, 78: 2101-2111.

http://dx.doi.org/10.1099/0022-1317-78-8-2101

YUAN, Y.S., MAO, Y., CHUAN, Y.L., RUI, L.W., XIAO, C.W., SHI, M.L. REN, S.Z. 2013. Priming of Anti-Herbivore Defense in Tomato by Arbuscular Mycorrhizal Fungus and Involvement of the Jasmonate Pathway. J Chem Ecol, 39:1036-1044. http://dx.doi.org/10.1007/s10886-013-0312-1 